\title{
Rasio IgM/lgG Fase Akut Untuk Menentukan Infeksi Dengue Sekunder
}

\author{
Bagus Ngurah Putu Arhana
}

\begin{abstract}
Latar belakang. Uji hemaglutinasi inhibisi (HI) memerlukan waktu relatif lama untuk menentukan infeksi dengue primer dan sekunder, karena memerlukan pemeriksaan serum pada fase akut dan konvalesen. Beberapa penelitian dengan menggunakan rasio IgM/ IgG untuk menentukan infeksi primer dan sekunder menghasilkan rasio yang berbedabeda.

Tujuan. Untuk mengetahui gambaran IgM dan IgG pada infeksi Dengue dan akurasi rasio IgM/IgG secara Elisa pada fase akut untuk menentukan infeksi sekunder.

Metoda. Dilakukan uji diagnostik pada sampel yang diambil secara berkesinambungan (consecutive sampling) pada 62 anak yang dicurigai menderita demam berdarah dengue antara Juli 2003 sampai dengan Juni 2004, dengan menggunakan rasio IgM/IgG secara Elisa pada fase akut. Uji Hambatan Hemaglutinasi sesuai dengan kriteria WHO sebagai baku emas.

Hasil. Dari 62 anak yang ikut dalam penelitian ini, ditemukan 48 anak dengan infeksi sekunder dan 14 anak dengan infeksi primer. Kadar rerata IgG pada anak dengan DBD baik syok maupun tidak lebih tinggi secara bermakna daripada demam dengue. Prevalensi infeksi sekunder adalah 77,4\%. Cut off point paling baik dari rasio IgM/ IgG sebagai prediktor infeksi sekunder adalah $\leq 0,9$ (sensitivitas $87,5 \%$, spesifisitas 92,9\%, rasio kemungkinan 12,3). Prevalensi dari syok pada infeksi sekunder adalah $16,7 \%$. Cut off point paling baik dari rasio kadar IgG sebagai prediktor SSD pada infeksi sekunder adalah $\geq 165,0 \mathrm{U} / \mathrm{mL}$ (sensitivitas $87,5 \%$, spesifisitas $97,5 \%$, rasio kemungkinan 35,0).

Kesimpulan. Kadar rerata IgG pada DBD nonsyok dan DBD syok secara bermakna lebih tinggi daripada demam dengue. Rasio IgM/IgG $\leq 0,9$ dapat dipakai sebagai prediktor infeksi sekunder dan kadar IgG $\geq 165,0 \mathrm{U} / \mathrm{mL}$ dapat dipakai sebagai prediktor terjadinya syok pada infeksi sekunder.
\end{abstract}

Kata kunci: DBD, infeksi primer dan sekunder, rasio IgM/IgG.

Alamat korespondensi:

Dr. Bagus Ngurah Putu Arhana, SpA(K), Bagian/SMF Ilmu Kesehatan Anak, FK Unud/RS Sanglah Denpasar, Jalan P Nias, Denpasar. Tel. (0361)227911-227915 Pes. 128. Fax. (0361)244038

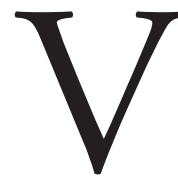

irus Dengue merupakan virus dengan penularan melalui gigitan nyamuk dari famili Flaviviridae dan terdiri dari empat serotipe (den 1-4). ${ }^{1,2}$ Kurang lebih 50 juta orang di dunia terinfeksi virus dengue, dan lebih dari 2,5 miliar orang berisiko terinfeksi dengue di daerah 
tropis dan dan sub-tropis. ${ }^{3}$ Distribusi infeksi dengue ini sesuai dengan fakta bahwa nyamuk mempunyai distribusi luas di daerah tropis dan sub-tropis menyebabkan infeksi dengue sebagai salah satu masalah kesehatan paling penting. ${ }^{4}$ Manifestasi klinis infeksi dengue bervariasi dari tanpa gejala, gejala ringan sampai berat, ${ }^{5,6}$ dan manifestasi klinis penyakit yang lebih berat ini dikaitkan dengan terjadinya fenomena perdarahan dengan kebocoran plasma pada demam berdarah dengue (DBD), yang terutama mengenai anak-anak muda. ${ }^{6,7}$ Kejadian DBD dan SSD paling banyak pada orang yang sebelumnya telah mempunyai antibodi dengue. ${ }^{8}$ Pada infeksi primer IgM antidengue muncul lebih dahulu daripada IgG dan biasanya terdeteksi pada hari ke- 5 dan menurun dalam 1-2 bulan. Pada infeksi sekunder IgG anti-dengue cepat meninggi dan IgM produksinya sedikit. Perbedaan pada sub-klas IgG dapat menentukan aktifasi komplemen dan ikatan reseptor Fcg. Faktor ini juga berperan dalam perkembangan antibody dependant enhancement (ADE) serta patogenesis DBD h. ${ }^{6,7,9}$

Rasio IgM dan IgG serum pada fase akut dapat digunakan untuk membedakan infeksi primer dan sekunder ${ }^{10}$ namun WHO sampai saat ini masih menggunakan uji hambatan hemaglutinasi sebagai baku emas untuk menentukan infeksi primer dan sekunder pada DBD. ${ }^{11}$

Tujuan penelitian ini untuk mengetahui kadar IgM dan IgG pada infeksi dengue dan akurasi rasio IgM/ IgG secara Elisa pada fase akut untuk menentukan infeksi primer dan sekunder.

\section{Bahan dan Cara Kerja}

Penelitian ini merupakan uji diagnostik untuk menilai akurasi IgM/IgG berdasarkan uji Elisa anti-dengue untuk menentukan infeksi sekunder pada DBD dengan menggunakan uji hambatan hemaglutinasi sebagai baku emas. Penelitian dilaksanakan di Sub Divisi Infeksi Tropis, Bag/SMF Ilmu Kesehatan Anak, FK Unud/Rumah Sakit Sanglah Denpasar, mulai tanggal 1 Juli 2003 - 30 Juni 2004. Pengumpulan data dilakukan secara prospektif dan subyek diambil secara consecutive sampling sampai jumlah subyekl terpenuhi (sesuai dengan perhitungan jumlah sampel minimal). Subyek penelitian adalah anak dengan diagnosis klinis suspek DBD yang menjalani rawat inap, dengan kriteria inklusi yaitu anak berumur lebih dari satu tahun, titer $\operatorname{IgM} \geq 1,0$ unit $/ \mathrm{mL}$, dan bersedia mengikuti penelitian. Anak tidak diikutkan dalam penelitian, jika menderita DM, sickle cell anemia, atau mendapat pengobatan imunosupresif.

Diagnosis klinis DBD ditegakkan berdasarkan kriteria WHO tahun $1997 .{ }^{11}$ Batasan yang dipergunakan dalam penelitian ini adalah,

- DBD adalah DBD derajat I dan II.

- SSD adalah DBD derajat III dan IV.

- Demam dengue (DD) adalah manifestasi klinis infeksi dengue yang dibuktikan dengan uji hambatan hemaglutinasi, tanpa disertai tanda kebocoran plasma. ${ }^{11}$

- Infeksi primer: infeksi virus dengue yang ditandai oleh adanya kenaikan titer antibodi hambatan hemaglutinasi $\geq 4$ dengan titer $\leq 1: 1280$ pada fase konvalesen. ${ }^{11}$

- Infeksi sekunder: infeksi virus dengue yang ditandai oleh adanya kenaikan titer antibodi hambatan hemaglutinasi $\geq 4$ kali dengan titer $\geq$ 1:2560 pada fase konvalesen. ${ }^{11}$

- Drop out adalah subyek yang telah ikut penelitian, namun dalam perawatan subyek meninggal, menolak melanjutkan penelitian atau tidak kontrol setelah dipulangkan dari rumah sakit.

Subyek drop out diganti dengan pasien baru sampai tercapai jumlah sampel minimal 62 anak. Selanjutnya pasien/orang tua diminta mengisi dan menandatangani inform concent. Jika setuju, diwawancarai oleh peneliti dengan menggunakan kuesioner, dan dilakukan pencatatan terhadap hasil pemeriksaan fisik serta perkembangan klinis yang berhubungan dengan gejala DBD. Penanganan selama di RS dilaksanakan sesuai prosedur tetap yang berlaku. Selama dirawat diambil sampel darah $1 \mathrm{~mL}$ tiap hari untuk pemeriksaan hemoglobin, leukosit, hematokrit dan trombosit. Pemeriksaan darah tepi juga dilakukan pada fase konvalesen (saat kontrol setelah dipulangkan) pada subyek yang tidak mengalami hemokonsentrasi selama fase akut. Pengambilan sampel darah fase akut untuk pemeriksaan uji HI, IgM dan IgG dengan tehnik Elisa dilakukan pada hari sakit ke-5/6. Untuk uji HI fase konvalesen pengambilan sampel darah dilakukan 2-3 minggu setelah pengambilan yang pertama. Sampel yang telah memenuhi kriteria inklusi dibagi menjadi dua kelompok didasarkan atas hasil uji hambatan hemaglutinasi sesuai kriteria WHO. Penelitian ini telah disetujui oleh Komite Penelitian dan Pengembangan RS Sanglah/FK Unud. 
Anak yang memenuhi kriteria infeksi sekunder dimasukkan ke dalam kelompok infeksi sekunder, dan yang lain dimasukkan ke dalam kelompok infeksi primer. Masing-masing kelompok diuraikan karakteristik klinis, dan laboratorium. Selanjutnya dihitung rerata umur, berat badan, kadar IgM, IgG dan rasio IgM/IgG dan dijabarkan pula jenis kelamin, dan manifestasi klinis masing-masing kelompok

Pengolahan data mempergunakan program Statistical Product and Service Solutions (SPSS) 11.5 for Windows. Uji $t$ dilakukan untuk mengetahui perbedaan kadar rerata IgM dan IgG antara demam dengue dan bukan demam dengue (DBD dan SSD), selanjutnya dihitung nilai sensitifitas, nilai spesifisitas, nilai duga positif, nilai duga negatif, akurasi, dan rasio kemungkinan dari nilai cut off rasio IgM/IgG. Nilai cut-off ditentukan dengan menggunakan kurva receiver operator characteristic (ROC).

\section{Hasil Penelitian}

\section{Karakteristik Subyek}

Selama periode penelitian Juli 2003 sampai dengan Juni 2004 dari 191 anak yang didiagnosis suspek DBD, 67 anak memenuhi kriteria penelitian, 5 anak drop out terdiri dari 4 anak tidak datang pada pengambilan darah uji HI pada fase konvalesen, 1 anak oleh karena sampel darah tidak memenuhi syarat, sehingga hanya 62 anak yang dapat dinterpretasi hasil uji HI. Di dapatkan $48(77,4 \%)$ anak mengalami infeksi sekunder, $14(22,6 \%)$ anak dengan infeksi primer. Manifestasi klinis anak dengan infeksi sekunder adalah demam dengue pada 17 anak, DBD non syok pada 23 anak, dan DBD syok pada 8 anak. Sedangkan 14 anak dengan infeksi primer semuanya termasuk dalam demam dengue. Kadar rerata IgM dan rasio IgM/IgG lebih tinggi pada kelompok infeksi primer, sedangkan kadar rerata IgG lebih tinggi pada kelompok infeksi sekunder (Tabel 1)

\section{Uji diagnostik rasio IgM/lgG untuk menentukan infeksi sekunder}

Dilakukan uji diagnostik untuk mencari nilai cut off rasio $\mathrm{IgM} / \mathrm{IgG}$ sebagai uji untuk menentukan infeksi sekunder. Didapatkan rasio $\operatorname{IgG}: \operatorname{Ig} M \leq 0,9$ merupakan nilai terbaik sebagai uji diagnostik untuk menentukan infeksi sekunder dengan nilai sensitifitas $87,5 \%$, spesifitas $92,9 \%$, nilai ramal positif (NRP) $97,7 \%$, nilai ramal negatif (NRN) $68,4 \%$, akurasi $88,7 \%$, dan dengan rasio kemungkinan (RK) 12,3. Untuk menunjukkan tingkat sensitifitas dan spesifisitas dari rasio IgM/IgG dalam menentukan infeksi sekunder pada masing-masing nilai cut-off digam barkan dengan kurva receiver operator characteristic (ROC) (Gambar1).

\section{Uji diagnostik kadar IgG untuk menen- tukan Dengue Syok pada infeksi sekunder}

Dilakukan uji diagnostik untuk mencari nilai cut off kadar IgG sebagai uji untuk menentukan SSD pada infeksi sekunder. Didapatkan kadar IgG $\geq 165,0$ U/ mL sebagai prediktor untuk menentukan SSD dengan nilai sensitifitas $87,5 \%$, spesifisitas $97,5 \%$, NRP 87,5\%, NRN 97,5\%, akurasi 95,8\%, dan dengan RK 35,0. Untuk menunjukkan bagaimana tingkat sensitifitas dan spesifisitas dari kadar IgG untuk menentukan DBD syok pada masing-masing nilai cutoff digambarkan dengan kurva ROC.(Gambar 2)

\section{Diskusi}

Pada karakteristik dasar nampak kadar rerata IgM dan rasio $\mathrm{IgM} / \mathrm{IgG}$ lebih tinggi pada kelompok infeksi primer, sebaliknya kadar rerata IgM lebih rendah pada kelompok infeksi sekunder. Untuk mengeliminasi virus pada infeksi pertama kali peran IgM permukaan sel plasma sangat penting. Adanya IgM permukaan ini menyebabkan sel plasma menghasilkan IgM dalam waktu singkat dan dalam jumlah yang banyak. Pada infeksi sekunder peran IgM diambil alih oleh IgG sehingga produksi IgM menjadi tidak sebesar pada infeksi primer. ${ }^{12,13}$

Manifestasi klinis kelompok infeksi sekunder tampak lebih berat, dari pada kelompok infeksi primer (semuanya demam dengue)(Tabel 1). Dari 62 subyek yang ikut dalam penelitian, 48 (77\%) merupakan infeksi sekunder, sisanya 14 (23\%) infeksi primer. Tujuh belas (35\%) dari 48 subyek yang mengalami infeksi sekunder bermanifestasi sebagai demam dengue, 23 (48\%) DBD non syok, dan 8 (17\%) sebagai DBD syok. Empat belas anak dengan infeksi 
Sari Pediatri, Vol. 8, No. 1, Juni 2006

Tabel 1. Karakteristik subyek

\begin{tabular}{lcc}
\hline \begin{tabular}{l} 
Karakteristik demografi, klinis, \\
\multicolumn{1}{c}{ dan laboratorium }
\end{tabular} & $\begin{array}{c}\text { Infeksi sekunder } \\
(\mathrm{n}=48)\end{array}$ & $\begin{array}{c}\text { Infeksi primer } \\
(\mathrm{n}=14)\end{array}$ \\
\hline Jenis kelamin, n(\%) & Laki-laki & $6(42,9)$ \\
Perempuan & $27(56,3)$ & $8(57,1)$ \\
Umur, bulan, rerata (SD) & $21(43,7)$ & $61.36(38,81)$ \\
Berat badan, kg, rerata (SD) & $70,83(29,57)$ & $19.50(8,89)$ \\
IgM (u/mL), rerata (SD) & $20,77(7,64)$ & $71,30(37,39)$ \\
IgG (u/mL), rerata (SD) & $38,23(25,52)$ & $12,31(13.55)$ \\
Rasio IgM/IgG & $103,72(61,39)$ & $9,40(6,74)$ \\
Manifestasi klinis, n (\%) & $0,95(2,29)$ & $14(100,0)$ \\
Demam dengue & & $0(0,0)$ \\
DBD non syok & $17(35,4)$ & $0(0,0)$ \\
DBD syok & $23(47,9)$ & $8(16,7)$ \\
\hline
\end{tabular}

Tabel 2 menunjukkan bahwa kadar rerata IgG pada DBD lebih tinggi secara bermakna dibandingkan dengan pada kelompok DD.

Tabel 2. Perbandingan kadar rerata IgM dan IgG pada DD dan DBD

\begin{tabular}{ccccc}
\hline $\begin{array}{c}\text { Kadar } \\
(\mathrm{U} / \mathrm{mL})\end{array}$ & $\mathrm{DD}$ & $\mathrm{DBD}$ & & \\
& $(\mathrm{N}=31)$ & $(\mathrm{N}=31)$ & $95 \% \mathrm{CI}$ & $\mathrm{p}$ \\
\hline $\mathrm{IgM}$, rerata (SD) & $53,22(32,95)$ & $38,17(28,62)$ & $(-0,63634)-(30,72021)$ & 0,06 \\
$\mathrm{IgG}$, rerata (SD) & $48,69(44,98)$ & $117,47(67,34)$ & $(-97,87673-(-39,69101)$ & 0,000 \\
\hline
\end{tabular}

Uji $\boldsymbol{t}$, bermakna $\mathrm{p}<0,05$

Kadar rerata $\mathrm{IgG}$ pada DBD syok jauh lebih tinggi dibandingkan dengan pada penderita dengan DBD. (Tabel 3)

Tabel 3. Perbandingan kadar rerata IgM dan IgG antara penderita DD, DBD non syok, dan DBD syok

\begin{tabular}{cccc}
\hline $\begin{array}{c}\text { Kadar } \\
(\mathrm{U} / \mathrm{mL})\end{array}$ & $\begin{array}{c}\mathrm{DD} \\
(\mathrm{n}=31)\end{array}$ & $\begin{array}{c}\text { non syok } \\
(\mathrm{n}=23)\end{array}$ & $\begin{array}{c}\text { DBD syok } \\
(\mathrm{n}=8)\end{array}$ \\
\hline IgM, rerata (SD) & $53,22(32,95)$ & $41,33(31,03)$ & $29,09(18,88)$ \\
$\mathrm{IgG}$, rerata (SD) & $48,69(44,98)$ & $85,83(40,51)$ & $208,46(39,05)$ \\
\hline
\end{tabular}

primer semua menderita demam dengue, dan semua DBD baik syok maupun tidak (100\%) adalah infeksi sekunder. Halstead (dikutip dari Sumarno ${ }^{14}$ ) mendapatkan bahwa tidak semua pasien DBD terjadi pada infeksi sekunder. Pada infeksi primer dapat bermanifestasi sebagai DBD baik syok maupun tidak, tetapi hampir semua pasien yang mengalami syok terjadi pada infeksi sekunder. Teori virulensi menyatakan bahwa untuk timbulnya DBD tidak perlu dua kali infeksi, satu kali saja cukup bila virus penyebab virulen. Galur serotipe den-2 diketahui mempunyai virulensi yang berpotensi menimbulkan gejala berat. ${ }^{13}$ Untuk mengidentifikasi adanya galur tersebut diperlukan teknik isolasi virus.

Penelitian rasio IgM/IgG untuk menentukan infeksi primer dan sekunder menunjukkan hasil yang berbeda. Pada penelitian kami, rasio $\operatorname{IgM} / \operatorname{IgG} \leq 0,9$ dapat digunakan untuk menentukan infeksi sekunder dengan sensitifitas $87,5 \%$, spesifisitas $92,9 \%$, nilai ramal positif $97,7 \%$, nilai ramal negatif $68,8 \%$, akurasi 


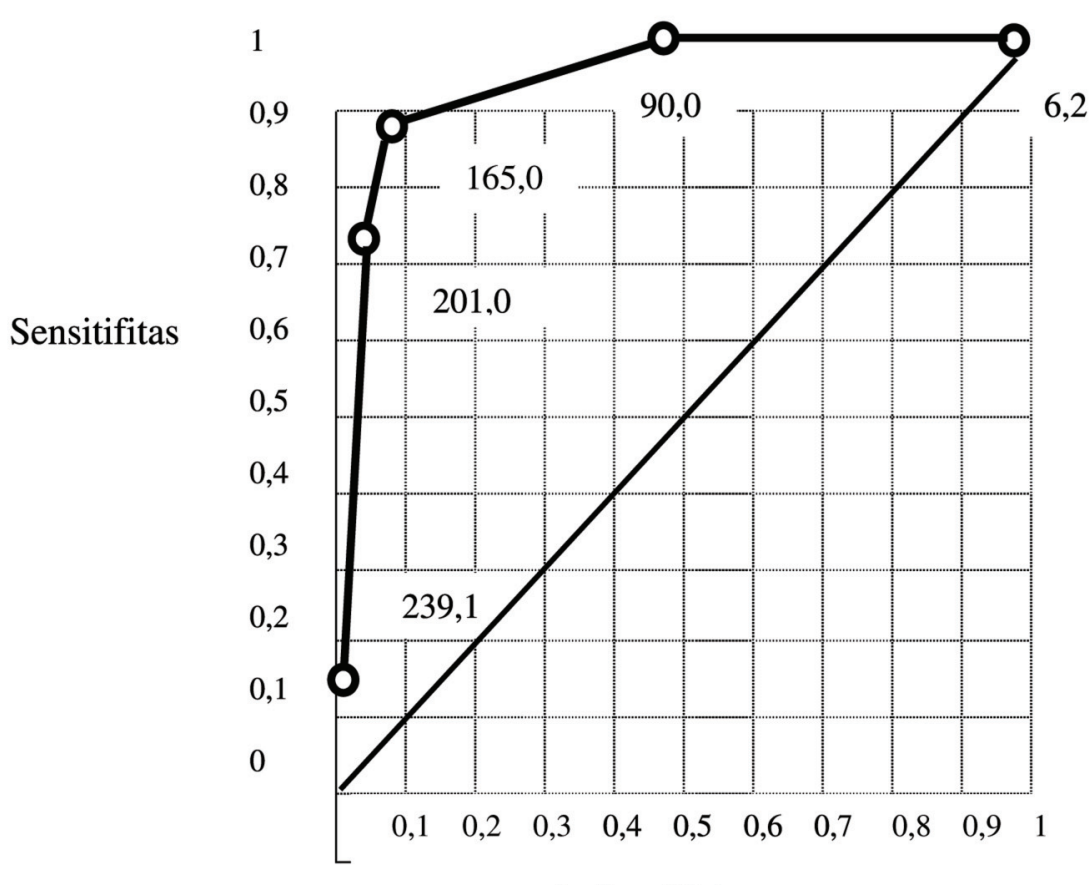

1- Spesifisitas

Gambar 2. Kurva ROC IgG sebagai prediktor untuk menentukan dengue syok pada infeksi sekunder dalam berbagai nilai cut-off kadar IgG (unit/mL)

$88,7 \%$, dan dengan rasio kemungkinan 12,3 . Penelitian oleh Innis dkk. ${ }^{15}$ yang dilakukan di Thailand dengan menggunakan uji hemaglutinasi inhibisi sebagai baku emas, nilai cut-off dari rasio $\operatorname{IgM} / \mathrm{IgG}$ pada infeksi sekunder adalah $\leq 0,56$ dengan sensitifitas $92 \%$ dan spesifi-sitas $96 \%$. Sai Kit Lam dkk. ${ }^{16}$ pada penelitiannya di Malaysia mendapatkan nilai cut off rasio $\operatorname{IgM} / \operatorname{IgG} \leq 0,5$ pada infeksi sekunder dengan sensitifitas 95\% dan spesifisitas 94\%. Hasil yang hampir sama pada penelitian Innis dan Sai Kit Lam tersebut mungkin karena Malaysia dan Thailand mempunyai seroepidemiologis hampir sama. Beda dengan penelitian kami, secara epidemiologis tempat penelitian kami memang beda dengan Malaysia dan Thailand. Selain itu, adanya kemungkinan reaksi silang dengan flavivirus lain. Adanya reaksi silang ini telah dibuktikan oleh Pei dkk. ${ }^{17}$ yang pada penelitiannya di Cina mendapatkan, 10\% IgG pada pasien infeksi dengue menunjukkan cross-reactive dengan flavivirus lain.

Banyak penelitian yang telah dilakukan oleh para ahli untuk berusaha menjelaskan hubungan antara respon imun dan variasi manfestasi klinis yang timbul pada infeksi dengue. Pada manifestasi yang berat, penganut teori secondary heterologous infection yang kemudian diperkuat teori ADE menganggap antibodi cross-reactive dengue yang ada dan sel $\mathrm{T}$ merupakan sentral dari patogenesis infeksi dengue. Hipotesis ini menyatakan bahwa antibodi nonneutralisasi crossrective dari infeksi sebelumnya memfasilitasi masuknya virus dengue ke reseptor Fc pada monosit/makrofag. Peningkatan jumlah APC terinfeksi mengaktivasi prekursor sel $\mathrm{T}$ memori cross-rective yang ada dalam jumlah besar sebagai hasil infeksi oleh virus dengue heterologus sebelumnya. Selain mengakibatkan pelepasan mediator kimia yang menyebabkan kebocoran plasma dan peningkatan derajat penyakit, juga mengakibatkan sel plasma memproduksi antibodi IgG dalam jumlah besar, suatu antibodi heterotipik yang tidak efektif untuk mengeliminasi serotipe virus yang sedang menginfeksi. ${ }^{7}$ Pada penelitian kami, didapatkan kadar rerata IgG pada kelompok infeksi sekunder lebih tinggi dibandingkan dengan kelompok infeksi primer 103,72 (SD 61,39) versus 12,31 (SD 13,55). Berdasarkan manifestasi klinis didapatkan kadar rerata IgG pada subyek yang mengalami DBD baik syok maupun tidak lebih tinggi secara bermakna 
dibandingkan dengan yang mengalami DD 117,47 (SD 67,34) versus 48,69 (SD 44,98), 95\%CI (97,87673)-(39,69101). Dari 48 subyek yang mengalami infeksi sekunder, 17(35\%) sebagai Demam Dengue, 23 (48\%) sebagai DBD non syok, dan 8 (17\%) sebagai DBD syok dengan kadar rerata IgG cenderung bertambah tinggi sesuai dengan derajat penyakit $(48,69 ; 85,83 ; 208,46 \mathrm{U} / \mathrm{mL})$. Koroka dkk. ${ }^{18}$ berdasarkan korelasi antara kinetik subkelas imunoglobulin serum spesifik virus dengue menyimpulkan bahwa peningkatan kadar IgG antidengue terutama IgG1 dan IgG3 dapat dijadikan petanda risiko terjadinya DBD dan DBD syok. Pada penelitiannya didapatkan kadar IgG1 dan IgG3 pada DBD dan DBD syok lebih tinggi secara bermakna dibandingkan pada DD. Dijelaskan bahwa IgG1 dan IgG3 heterotipik yang terbentuk efektif mengikat komplemen, sehingga terjadi aktivasi komplemen yang selanjutnya menginduksi pembekuan dan mungkin koagulasi intravaskular yang memperberat derajat penyakit. Hasil yang kami dapat dan juga hasil penelitian Koroka dkk. sesuai dengan teori ADE.

Berdasarkan uji diagnostik untuk mencari nilai cutoff kadar $\mathrm{IgG} \geq 165,0$ unit $/ \mathrm{mL}$ dapat digunakan sebagai prediktor terjadinya Syok dengan sensitifitas $87,5 \%$, spesifisitas $97,5 \%$, nilai ramal positif $87,5 \%$, nilai ramal negatif $97,5 \%$, akurasi $95,8 \%$, dan rasio kemungkinan 35,0.

Kelemahan pada penelitian ini adalah jumlah sampel sedikit; variabel luar yang dapat mempengaruhi respon imun seperti umur, jenis kelamin, dan status gizi tidak dapat kami kendalikan karena pada uji diagnostik secara metodologi memang tidak memungkinkan untuk itu. Hal lain yang dapat mempengaruhi hasil penelitian adalah adanya kemungkinan reaksi silang dengan flavivirus lain pada subyek yang kami teliti, yang tidak dapat kami buktikan.

\section{Kesimpulan}

Kadar rerata IgG pada kelompok infeksi sekunder lebih tinggi dibandingkan dengan kelompok infeksi primer, dan kadar rerata IgG pada DBD baik yang mengalami syok atau tidak lebih tinggi secara bermakna dibandingkan dengan DD. Berdasarkan sensitifitas, spesifisitas, nilai ramal positif, nilai ramal negatif, akurasi, dan rasio kemungkinan, maka cut-off yang terbaik untuk menentukan infeksi sekunder adalah pada rasio $\mathrm{IgM} / \mathrm{IgG} \leq 0,9$ dan kadar $\mathrm{IgG} \geq 165,0 \mathrm{U} /$ $\mathrm{mL}$ pada infeksi sekunder baik sebagai prediktor terjadinya syok. Ratio IgM/IgG secara Elisa dapat dipakai untuk mendiagnosis tipe infeksi dengue karena hanya memerlukan satu kali pemeriksaan untuk menentukan tipe infeksi dan pada saat yang sama kadar IgG dapat digunakan sebagai prediktor terjadinya SSD.

\section{Daftar Pustaka}

1 Tabel 2 menunjukkan bahwa kadar rerata IgG pada DBD lebih tinggi secara bermakna dibandingkan dengan pada kelompok DD.

Ken-Ichiro Yamada, Tomohiko Taka-saki, Masaru Nawa, Sadao Yabe, Ichiro Kurane. Antibody responses determined for Japanese dengue fever patients by neutralization and hemagglutination inhibiton assays demonstrate cross-reactivity between dengue and Japanese encephalitis viruses. Clin Diagn Lab Immunol 2003; 10:725-8.

2. Katrin CL, Vaughan DW, Douglas MW. Dengue virus structural diffrences that correlate with pathogenesis. J Virol 1999; 73:4738-47.

3. Vanda AUFS, Silvana F, Evaldo SA. Use of an immunoglobulin $G$ avidity test to discriminate between primary and secondary dengue virus infections. J Clin Microbiol 2004; 42:1782-4.

4. Srisakul CK, Ananda N, Walter EB, Larry W, Donald B. Antibody dependent enhancement of dengue virus growth in human monocytes as a risk factor for dengue hemorrhagic fever. Am J Trop Med Hyg 1989;40:444-51.

5. Vaughn DW, Sharone G, Kalayanarooj S. Dengue in the early febrile phase: viremia and antibody responses. J Infect Dis 1997; 176:322-30.

6. Maria GG, Gustavo K. Advances in dengue diagnosis. Clin Diagn Lab Immunol 1996; 3: 621-7.

7. Robert A, Wang SL, Osiowy C, Issekutz AC. Activation of endothelial cells via antibody-enhanced dengue virus infection of peripheral blood monocytes. J Virol 1997; 71: 4226-32.

8. Juffrie M, K Haasnoot, LG Thijs. Dengue virus infection and dengue hemorrhagic shock. Crit \& Care 2000; 3:130-47.

9. Ohmann HB. Pathogenesis of dengue virus diseases: missing pieces in the jigsaw. Trend in Microbiol 1997; 5:409-12.

10. Alan L.R. Clinical presentation and diagnosis of dengue virus infection. UpToDate 2001; 9:1-7.

11. World Health Organization. Dengue haemorrhagic fever: 
diagnosis, treat-ment and control. Jenewa, 1997 .h. 1-83.

12. Feldmann M. Cell cooperation in the antibody response. Dalam: Roitt, Brostoff, Male, penyunting. Immunology. Edisi ke-5. Philadelphia: Mosby, 1998.h.139-50.

13. Sutaryo. Dengue. Edisi pertama. Yogyakarta: Medika Fakultas Kedokteran Unversitas Gajah Mada, 2004.h.1-241.

14. Sumarmo. The epidemiology control and prevention of dengue hemorrhagic fever (DHF) in Indonesia. Cermin Dunia Kedokteran 1994;92: 5-10.

15 Innis BL, Nisalak S, Nimmannitya S. An enzyme-linked immunosorbent assay to characterize dengue infections where dengue and Japanese encephalitis co-circulate. Am J Trop Med Hyg 1989; 40:418-27.

16. Sai Kit Lam, Cheng Lan Ew, Jody L Mitchell, Andre J
C, Peter L Devine. Evaluation of a capture screening enzyme-linked immunosorbent assay for combined determination of immunoglobulin $\mathrm{M}$ and $\mathrm{G}$ antibodies produced during dengue infection. Clin Diagn Lab Immunol 2000; 7:850-2.

17. Pei YS, Li KC, Shu FC. Comparison of capture imunoglobulin $M$ (IgM) and IgG enzym-linked immunoabsorbent assay (ELISA) and nostructural protein NS1 serotype-specific IgG ELISA for differentiation of primary and secondary dengue virus infections. J Clin Immunol 2003; 10:622-30.

18. Koroka P, Suharti C, Setiati E. Kinetics of dengue-specific serum immunoglobulin classes and subclasses correlate with clinical outcome infection. J Clin Microbiol 2001;39:4332-8 